\title{
Antifungal Activity and Phytotoxicity of Vitex simplicifolia Oliv. Leaves Essential Oil
}

\author{
Issa Gamsore ${ }^{1}$, Lassina Ouattara ${ }^{2}$, Paulin Ouoba $^{2}$, Schémaeza Bonzi $^{3}$ \& Irénée Somda ${ }^{3}$ \\ ${ }^{1}$ Centre Agricole Polyvalent de Matourkou, Bobo-Dioulasso, Burkina Faso \\ 2 Unité de Formation et de Recherche en Sciences et Techniques, Département de Sciences Biologiques, \\ Université Nazi Boni de Bobo-Dioulasso, Bobo-Dioulasso, Burkina Faso \\ ${ }^{3}$ Laboratoire de Phytopathologie, Institut du Développement Rural, Université Nazi Boni de Bobo-Dioulasso, \\ Bobo-Dioulasso, Burkina Faso \\ Correspondence: Lassina Ouattara, Unité de Formation et de Recherche en Sciences et Techniques (UFR-ST), \\ Département de Sciences Biologiques, Université Nazi Boni, 01 BP 1091 Bobo-Dioulasso 01, Burkina Faso. \\ E-mail: lasouatt@yahoo.fr
}

$\begin{array}{lc}\text { Received: July 15, } 2018 & \text { Accepted: August 18, } 2018 \quad \text { Online Published: October 15, } 2018 \\ \text { doi:10.5539/jas.v10n11p203 } & \text { URL: https://doi.org/10.5539/jas.v10n11p203 }\end{array}$

\begin{abstract}
Agriculture faces many difficulties related to phytopathogenic fungi leading to quantitative and qualitative losses of crops. The use of essential oils against these fungi is one of the alternatives. This study focused on the antifungal activity and phytotoxicity of Vitex simplicifolia Oliv. leaves essential oil. Firstly, we extracted the essential oil from the leaves by hydrodistillation. Subsequently, seven fungal isolates were evaluated for their sensitivity to the essential oil on Potato Dextrose Agar (PDA) media at $0.1 ; 0.25$ and $0.50 \%$. Evaluation of the phytotoxicity of the essential oil was performed on sorghum seeds on a sterilized sand substrate. At the seventh day after incubation, the most sensitive fungi to the essential oil are Fusarium moniliforme, Colletotrichum graminicola and Curvularia lunata. The most sensitive fungus to the essential oil at $0.50 \%$ is Colletotrichum graminicola with $77.21 \%$ inhibition rate at the seventh day after incubation. Phytotoxicity evaluation showed that for all biomass parameters measured there is no significant difference between treatment with the essential oil and treatment with the fungicide control. At the end of this study, it appears that Vitex simplicifolia essential oil has a high antifungal activity. This essential oil has not shown toxicity on sorghum growth parameters. Therefore, this oil can be used in organic farming.
\end{abstract}

Keywords: essential oil, Vitex simplicifolia Oliv, antifungal, phytotoxicity

\section{Introduction}

In Burkina Faso, cereals production is focused on sorghum, millet, maize and rice. In 2016, total cereal production was estimated at 4736000 tons (FAOSTAT, 2016). This cereal production faces many difficulties related to the parasites such as phytopathogenic fungi (Somda, Sanou, \& Sanon, 2008) leading to quantitative and qualitative losses of crops. The most common control method of parasites is based on the use of chemicals (Hmiri et al., 2011). This method is limited by chemicals cost, environment pollution and human intoxication linked to anarchic use. The use of natural plant extracts against phytopathogenic fungi is one of the alternatives. Some extracts from plants have already been studied and have demonstrated their effectiveness in controlling phytopathogenic fungi (Nébié, 2006; Somda, Sanon, Michaud, \& Sanou, 2003; Ouoba et al., 2018). In this context we aimed to assess the antifungal activity of Vitex simplicifolia leaves essential oil on seven phytopathogenic fungi. Vitex simplicifolia is a shrub 2-6 m tall, short bole, open top. The leaves are opposite, whorled or sometimes alternate, simple or trifoliate, more or less pubescent on both sides. The flowers color are pink to purple. The fruit is a globose glabrous and blackish drupe at maturity (Arbonnier, 2002).

Preliminary studies carried out on this oil had shown that it was rich in terpene compounds (Ouoba, Koudou, Somé, \& Guissou, 2009). These terpene compounds are known to have antifungal properties (Nazzaro, Fratianni, Coppola, \& De Feo, 2017), which justifies the relevance of this study. 


\section{Materials and Method}

\subsection{Materials}

\subsubsection{Plant Material}

The plant material consists of Vitex simplicifolia leaves harvested during the months of May and June 2017 in the Dindéresso classified forest (Figure 1) and sorghum seeds of the local variety "kapelga" supplied by a company specialized in the production of certified seeds in Burkina Faso.

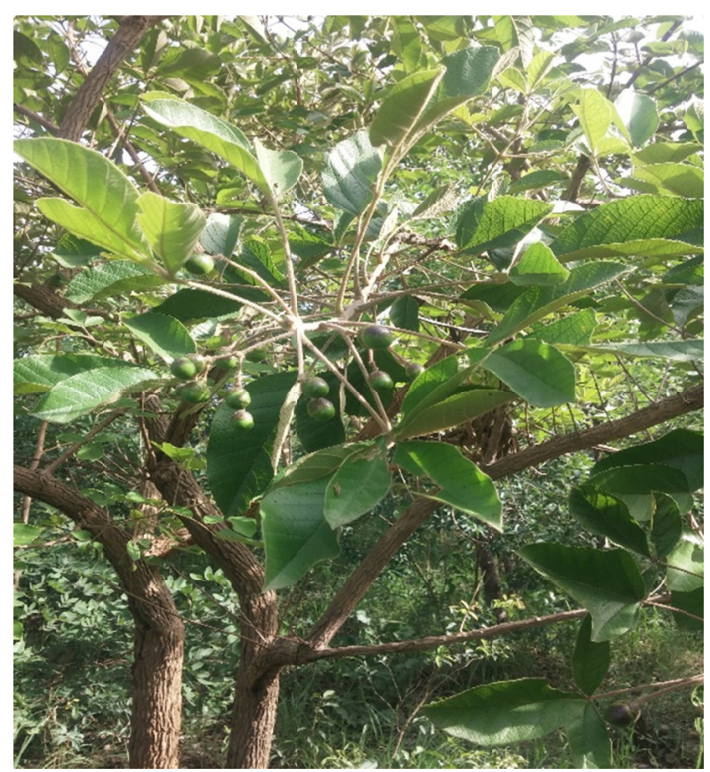

Figure 1. Vitex simplicifolia

\subsubsection{Fungal Material}

Fungi were provided by the Plant Clinic Laboratory of the Nazi Boni University (Table 1).

Table 1. Phytopathogenic fungi

\begin{tabular}{ll}
\hline phytopathogenic fungi & Origin \\
\hline Alternaria alternata (Fr) Keissler & Tomato (Solanum lycopersicum L) \\
Colletotricum dematium (Pers. Ex Fr) Grove & Cowpea (Vigna unguiculata (L.) Walp) \\
Colletotrichum graminicola (Ces) Wilson & Sorghum (Sorghum bicolor (L) Moench) \\
Curvularia lunata (Wakker) Boedijn & Maize (Zea mays L.) \\
Fusarium moniliform Sheldom & Sorghum (Sorghum bicolor (L) Moench) \\
Fusarium oxysporum F.sp. Radicis-Lycopersici (Sheld) & Tomato (Solanum lycopersicum L) \\
Fusarium verticillioides (Sacc) Nirenberg & Maize (Zea mays L.) \\
\hline
\end{tabular}

\subsection{Method}

\subsubsection{Leaves Harvesting and Essential Oil Extraction}

The harvest of the leaves was achieved in the Dindéresso classified forest, located at 15 kilometers in the western part of Bobo-Dioulasso city and transported to the shelter of light at the laboratory of Biochemistry of the University Nazi Boni.

Extraction of the essential oil was carried out by hydrodistillation (Ouattara et al., 2007) with a Clevenger type extractor. The principle is as follows: The leaves were stripped of their impurities, cut into small slices and introduced into a $500 \mathrm{ml}$ (29/32) flask containing distilled water and heated to gentle boiling. Water vapor and oil are entrained and condensed at the separator funnel. The different phases (oil/water) are separated by density difference. The essential oil is collected in a glass vial and dried with anhydrous sodium sulphate and stored at a 
temperature of $4{ }^{\circ} \mathrm{C}$. The average oil yield of three successive extractions was calculated according to the following formula:

$$
\mathrm{Y}=\left(\frac{\mathrm{m}}{\mathrm{M}}\right) \times 100
$$

Where, Y: essential oil yield; m: essential oil mass; M: plant material mass.

\subsubsection{Evaluation of Antifungal Activity in vitro: Mycelial Radial Growth}

Preparation of Culture Media: To evaluate mycelial growth, three treatments were carried out: the water control, the treatment with the essential oil and the fungicidal control. The water control is obtained by adding $4.2 \mathrm{~g}$ of Potato Dextrose Agar PDA (Liofilchem ${ }^{\circledR}$, Italy) in $100 \mathrm{ml}$ of distilled water. The mixture is autoclaved at $121{ }^{\circ} \mathrm{C}$ for 30 minutes. After cooling to $60{ }^{\circ} \mathrm{C}$, it is distributed in Petri dishes (Aptaca Italy) in aseptic conditions under a laminar flow hood (Napflow 12STD GV2EFR).

For the preparation of the medium containing the essential oil, $4.2 \mathrm{~g}$ of PDA were introduced into $100 \mathrm{ml}$ of distilled water. The mixture is sterilized as in the previous conditions. After cooling the culture medium to $60{ }^{\circ} \mathrm{C}$, we prepared media rich in essential oil at the concentration of $0.10 \%$ for all fungi tested. Two other media rich in essential oil at concentrations of 0.25 and $0.50 \%$ were prepared to test the fungi most sensitive to the essential oil at $0.10 \%$.

For the medium containing the fungicide Calthio C, $4.2 \mathrm{~g}$ of PDA were added to $100 \mathrm{ml}$ of distilled water and sterilized under the same conditions as above. After cooling to $60{ }^{\circ} \mathrm{C}, 0.4 \mathrm{~g}$ of Calthio $\mathrm{C}$ is added thereto.

Media Inoculation and Incubation: From a five-day-old colony, $5 \mathrm{~mm}$ diameter mycelial fragments were collected from the frontal portion in the active growth zone of each fungus. The explants were placed in the center of each Petri dish containing one of the culture media. The petri dishes thus inoculated were sealed with parafilm paper (Prafilm ${ }^{\circledR}$, Neemah, Wi54956) and incubated in an incubation chamber under 12 hours of near-UV light (PhilipsTLD 36W/08) and 12 hours in darkness for seven days (Mathur \& Kongsdal, 2003).

Measurement of Mycelial Growth: it was done four and seven days after incubation. For each evaluation of mycelial growth, an average of the different measurements is considered. The mycelial growth inhibition percentage is calculated according to the following formula:

$$
\mathrm{I}=\left[\frac{\mathrm{Dw}-\mathrm{Do}}{\mathrm{Dw}}\right] \times 100
$$

Where, I: inhibition percentage; Dw: average diameter of the water control; Do: average diameter of treatment with essential oil or fungicide.

\subsubsection{Phytotoxicity Assessment of the Essential Oil}

Phytotoxicity was assessed on sorghum (Mathur, Njala \&Kongsdal, 2003). Three treatments were performed due to 100 seeds per treatment. The different treatments are: The water control, the clay control, the fungicide control ( $20 \mathrm{~g}$ of Calthio $\mathrm{C}$ for $5 \mathrm{~kg}$ of sorghum seeds) and the essential oil at $0.5 \%$. The mass of the clay used is proportional to the mass of 100 seeds used. This mass is calculated according to the following formula (Zida, Lund, \& Néya, 2012; Ouoba et al., 2018):

$$
\mathrm{Mc}=\mathrm{A} \times\left(\frac{800}{5000}\right)
$$

Where, Mc: mass of clay; A: mass of 100 seeds

The treated seeds were incubated at room temperature for 24 hours and sown in pots containing sterile fine sand in four repetitions due to 25 seeds per repetition. After sowing, the pots were placed under a tunnel at room temperature. Root length, height, and weight of seedlings were evaluated on the fourth and tenth day after sowing. The measurement of these biometric growth parameters was performed on 10 seedlings randomly selected by repetition. The number of emerged plant at the different assessment dates was used to calculate the percentage of seedling emergence by the following formula:

$$
\mathrm{E}=\left(\frac{\mathrm{n}}{\mathrm{N}}\right) \times 100
$$

Where, E: percentage of emergence; $\mathrm{n}$ : the number of emerged seedlings and $\mathrm{N}$ : the number of seeds sown.

\subsection{Data Analysis}

Radial growth averages of each fungus and averages of emergence rate, root length, shoot height, and seedling mass for each treatment were compared. The variance analysis was performed using the Student Newman Keuls multiple classification test at the 5\% threshold. The XLSTAT version 2007 software was used. 


\section{Results and Discussion}

\subsection{Results}

\subsubsection{Extracting Yield}

After three extractions we obtained an average yield of essential oil of $0.35 \pm 0.01 \%$.

\subsubsection{Mycelial Growth}

The essential oil, at a concentration of $0.1 \%$, reduced the mycelial growth of four fungi i.e. C. lunata, C. dematium, F. moniliforme, and F. oxysporum fungi on the fourth day after incubation (Table 2). On the seventh day, the three most sensitive fungi to the essential oil are F. moniliforme, C.graminicola and C. lunata (Table 3).

Table 2. Effect of essential oil on mycelial growth of fungi tested after four days incubation

\begin{tabular}{llllllll}
\hline \multirow{2}{*}{ Treatment } & \multicolumn{7}{c}{ Mycelial growth $(\mathbf{c m})$} \\
\cline { 2 - 7 } & A. alter & C. luna & C. dema & C. grami & F. moni & F. oxys & F. vert \\
\hline Water control & $2.33 \mathrm{~b}$ & $4.48 \mathrm{c}$ & $2.33 \mathrm{c}$ & $2.21 \mathrm{~b}$ & $2.88 \mathrm{c}$ & $3.15 \mathrm{c}$ & $3.78 \mathrm{~b}$ \\
Fungicide control & $0.50 \mathrm{a}$ & $0.50 \mathrm{a}$ & $0.50 \mathrm{a}$ & $0.50 \mathrm{a}$ & $0.50 \mathrm{a}$ & $0.50 \mathrm{a}$ & $0.50 \mathrm{a}$ \\
Essential oil $(0.10 \%)$ & $2.40 \mathrm{~b}$ & $3.03 \mathrm{~b}$ & $2.18 \mathrm{~b}$ & $1.80 \mathrm{~b}$ & $2.05 \mathrm{~b}$ & $2.60 \mathrm{~b}$ & $3.53 \mathrm{~b}$ \\
$-p$-value & 0.0001 & 0.0001 & 0.0001 & 0.00023 & 0.0001 & 0.0001 & 0.0001 \\
\hline
\end{tabular}

Note. In the same column, the averages with the same alphabetical letter are not significantly different at the $5 \%$ threshold according to the Student Newman and Keuls test. A. alter: A. alternata; C. luna: C. lunata; $C$. dema: $C$. dematium; C. grami: C. graminicola; F. moni: F. moniliforme; F. oxys: F. oxysporum; F. vert: F. vertillioides.

Table 3. Effect of essential oil on mycelial growth of fungi tested after seven days incubation

\begin{tabular}{llllllll}
\hline \multirow{2}{*}{ Treatment } & \multicolumn{7}{c}{ Mycelial growth $(\mathbf{c m})$} \\
\cline { 2 - 7 } & A. alter & C. luna & C. dema & C. grami & $\boldsymbol{F}$. moni & $\boldsymbol{F}$. oxys & $\boldsymbol{F}$. vert \\
\hline Water control & $3.15 \mathrm{~b}$ & $9 \mathrm{c}$ & $3.833 \mathrm{~b}$ & $5.650 \mathrm{c}$ & $6.617 \mathrm{c}$ & $5.067 \mathrm{c}$ & $6.03 \mathrm{c}$ \\
Fungicide control & $0.50 \mathrm{a}$ & $0.50 \mathrm{a}$ & $0.50 \mathrm{a}$ & $0.50 \mathrm{a}$ & $0.50 \mathrm{a}$ & $0.50 \mathrm{a}$ & $0.50 \mathrm{a}$ \\
Essential oil $(0.10 \%)$ & $3.13 \mathrm{~b}$ & $6.70 \mathrm{~b}$ & $3.583 \mathrm{~b}$ & $4.067 \mathrm{~b}$ & $4.367 \mathrm{~b}$ & $4.30 \mathrm{~b}$ & $5.16 \mathrm{~b}$ \\
\hline p-value & 0.0001 & 0.0001 & 0.0001 & 0.0013 & 0.0001 & 0.0001 & 0.0001 \\
\hline
\end{tabular}

Note. In the same column, the averages with the same alphabetical letter are not significantly different at the $5 \%$ threshold according to the Student Newman and Keuls test. A. alter: A. alternata; $C$. luna: $C$. lunata; $C$. dema: $C$. dematium; C. grami: C. graminicola; F. moni: F. moniliforme; F. oxys: F. oxysporum; F. vert: F. vertillioides.

Table 4 gives the values of the mycelial growth respectively at 0.25 and $0.5 \%$ essential oil. The essential oil significantly reduced the growth of the three fungi. The most sensitive fungus is C.graminicola. For this fungus the treatment with the essential oil did not show any significant difference compared to the treatment with the fungicide control. Figures 2 and 3 illustrate the high sensitivity of this fungus to the essential oil. The data in Table 4 on mycelial growth made it possible to calculate the percentage inhibition of mycelial growth (Figure 4). At $0.5 \%$ in essential oil, the inhibition percentage varies from $45.58 \%$ to $77.21 \%$. At this concentration the maximum inhibition percentage for all these fungi is reached at the fourth day after incubation

Table 4. Effect of essential oil on mycelial growth four and seven days after incubation (DAI)

\begin{tabular}{|c|c|c|c|c|c|c|}
\hline \multirow{3}{*}{ Treatments } & \multicolumn{6}{|c|}{ Mycelial growth (cm) } \\
\hline & \multicolumn{2}{|c|}{ C. lunata } & \multicolumn{2}{|c|}{ C. graminicola } & \multicolumn{2}{|c|}{ F. moniliforme } \\
\hline & 4 DAI & 7DAI & 4 DAI & 7DAI & 4 DAI & 7DAI \\
\hline Water control & $6.23 \mathrm{~d}$ & $7.35 \mathrm{~d}$ & $3.70 \mathrm{c}$ & $7.81 \mathrm{c}$ & $4.41 \mathrm{~d}$ & $7.73 \mathrm{~d}$ \\
\hline Fungicide control & $0.50 \mathrm{a}$ & $0.50 \mathrm{a}$ & $0.50 \mathrm{a}$ & $0.50 \mathrm{a}$ & $0.50 \mathrm{a}$ & $0.50 \mathrm{a}$ \\
\hline Essential oil $(0.25 \%)$ & $2.33 \mathrm{c}$ & $2.90 \mathrm{c}$ & $1.33 b$ & $1.95 b$ & $2.96 \mathrm{c}$ & $5.05 \mathrm{c}$ \\
\hline Essential oil $(0.50 \%)$ & $1.96 \mathrm{~b}$ & $2.43 b$ & $0.63 \mathrm{a}$ & $1.78 \mathrm{~b}$ & $2.40 \mathrm{~b}$ & $4.18 \mathrm{c}$ \\
\hline p-value & 0.0001 & 0.0001 & 0.0001 & 0.0001 & 0.0001 & 0.0001 \\
\hline
\end{tabular}

Note. In the same column, the averages with the same alphabetical letter are not significantly different at the $5 \%$ threshold according to the Student Newman and Keuls test. 


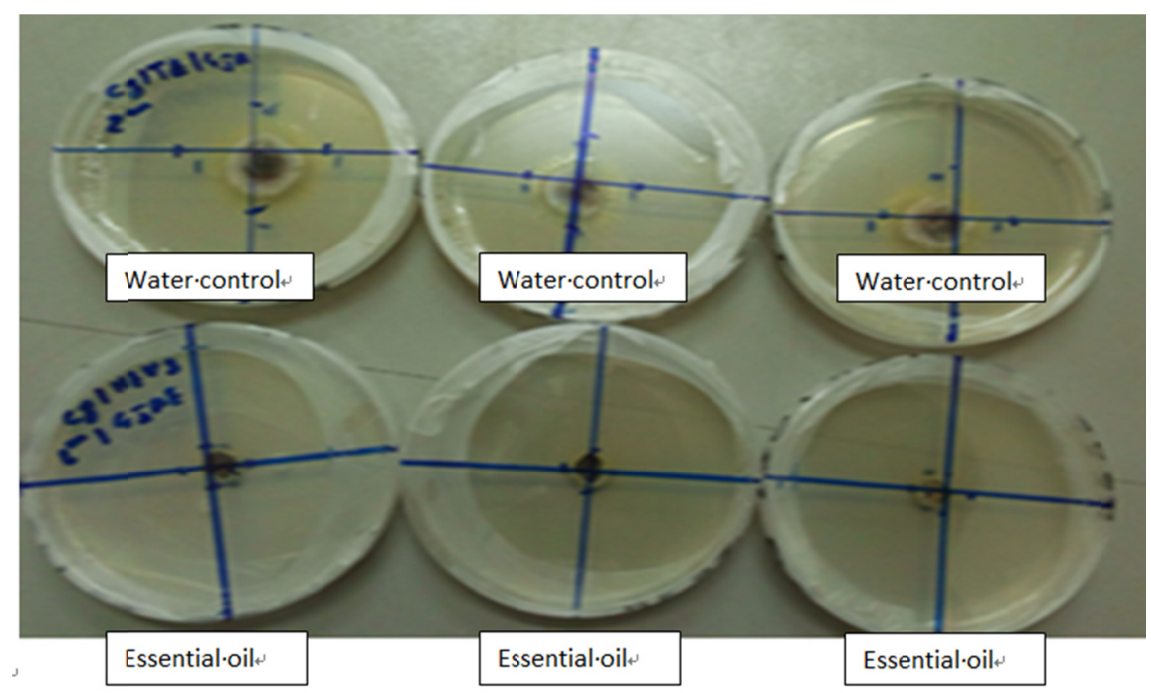

Figure 2. Mycelial growth of C.graminicola seven days after incubation in presence of essential oil at $0.25 \%$

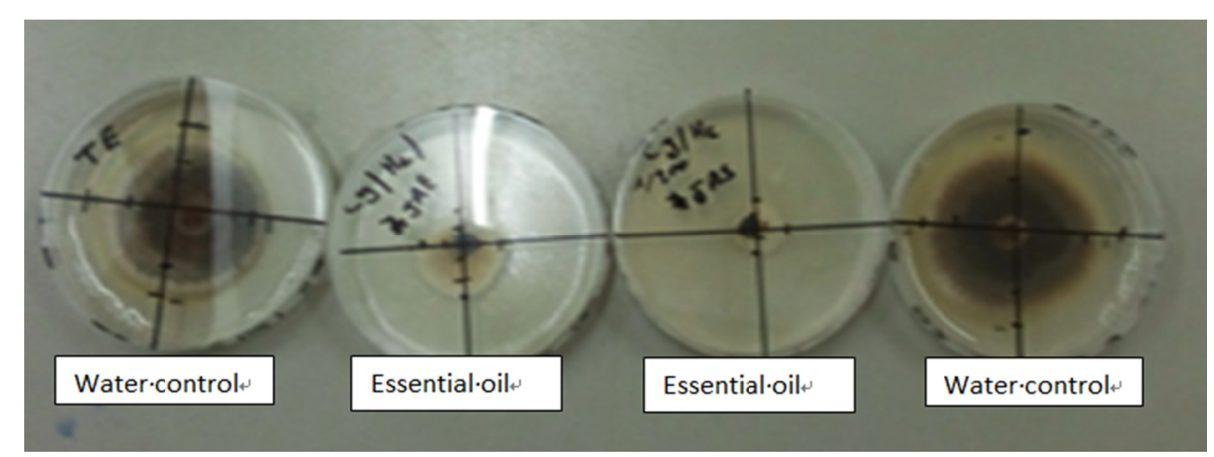

Figure 3. Mycelial growth of C.graminicola seven days after incubation in presence of essential oil at $0.50 \%$

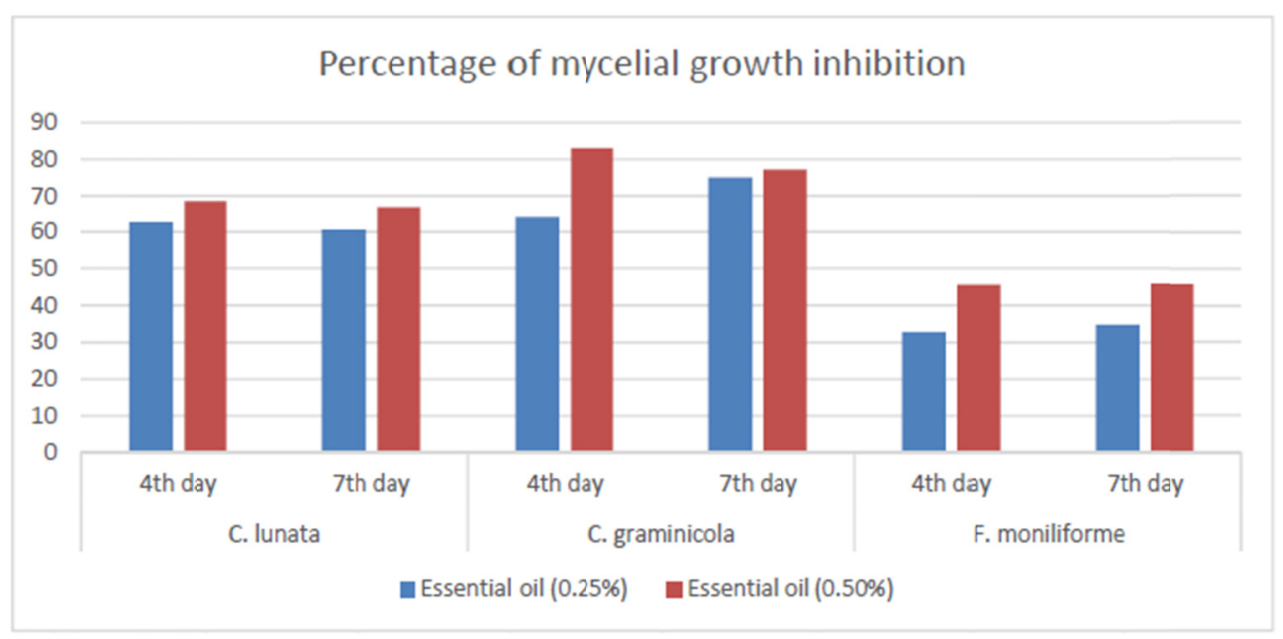

Figure 4. Inhibition percentage of the three most sensitive fungi to the essential oil four and seven days after incubation 


\subsubsection{Phytotoxicity of the Essential Oil on Sorghum}

Table 5 gives the emergence rate, the averages of roots and stems lengths and that of the biomass. These results show that there is no significant difference for all these parameters between the treatment with the essential oil and the treatment with the fungicide control. The essential oil does not affect the growth of sorghum seedlings.

Table 5. Effects of treatments on the emergence, length and biomass of Sorghum seedlings

\begin{tabular}{lllll}
\hline Treatments & Emergence rate (\%) & Roots length $\mathbf{( c m )}$ & Stems length $(\mathbf{c m})$ & Mass $(\mathbf{g})$ \\
\hline Water control & $90 \mathrm{a}$ & $33.75 \mathrm{~b}$ & $11.90 \mathrm{a}$ & $0.27 \mathrm{a}$ \\
Fungicide control & $87 \mathrm{a}$ & $30.07 \mathrm{a}$ & $13.24 \mathrm{a}$ & $0.26 \mathrm{a}$ \\
Clay control & $91 \mathrm{a}$ & $28.91 \mathrm{a}$ & $12.78 \mathrm{a}$ & $0.24 \mathrm{a}$ \\
Essential oil $(0.50 \%)$ & $89 \mathrm{a}$ & $29.66 \mathrm{a}$ & $11.99 \mathrm{a}$ & $0.28 \mathrm{a}$ \\
\hline -value & 0.81 & 0.03 & 0.16 & 0.23
\end{tabular}

Note. In the same column, the averages with the same alphabetical letter are not significantly different at the $5 \%$ threshold according to the Student Newman and Keuls test.

\subsection{Discussion}

The extraction of the essential oil from the leaves of Vitex simplicifolia gave a yield of $0.35 \%$. This value is in the yield range obtained by Nebié (2006) on the same plant which was 0.31 to $0.55 \%$. It is relatively weaker than that obtained by Ouoba, Koudou, Somé, and Guissou (2009) which was $0.8 \%$. Several factors such as harvest period, age of plant, stage of growth, pedoclimatic conditions, distilled part and extracting method may explain these differences (Satrani, 2001).

Taking into account the results on mycelial growth, there was a variable sensitivity to the essential oil of the seven fungi. At a concentration of $0.1 \%$ essential oil there was a reduction in mycelial growth of four fungi $C$. lunata, $C$. dematium, F. moniliforme, F. oxysporum at the fourth day after incubation. On the seventh day, the three most sensitive fungi are F.moniliforme, C. graminicola and C. lunata. These three fungi having been tested at 0.25 and $0.50 \%$ essential oil showed inhibition percentages ranging from $32.88 \%$ to $82.97 \%$ at the fourth day after incubation. This essential oil at $0.5 \%$ significantly reduced mycelial growth of $C$ lunata, $C$ graminicola and $F$. moniliforme with a higher activity on $C$ graminicola $(77.21 \%)$ on the seventh day after incubation. These results show that this essential oil is endowed with antifungal activity. This could be explained by the nature of its chemical composition. Indeed, the work of Ouoba, Koudou, Somé, and Guissou (2009) on the chemical composition of the leaves of Vitex simplicifolia has shown that it contains mainly $71.02 \%$ of monoterpenoids, $64.70 \%$ of monoterpene hydrocarbons and $22.03 \%$ of sesquiterpene hydrocarbons with myrcene as major compound $(53.50 \%)$. Several authors have shown that essential oils rich in monoterpenoids may have inhibitory activities on fungi (Hmiri et al., 20011) such as C. graminicola, F. moniliforme (Ouoba et al., 2018) and C. lunata (Ouoba et al., 2018; Gbogbo et al., 2005). These monoterpenes act on the mitochondria membrane of fungal cells and block their functioning (Nazzaro, Fratianni, Coppola, \& De Feo, 2017; Yoshimura, Sawai, Tamotsu, \& Sakai, 2011). For the three fungi tested at 0.25 and $0.50 \%$ essential oil, only $F$. moniliforme has an inhibition percentage less than $50 \%$ at the fourth $(45.58 \%)$ and at the seventh day $(45.92 \%)$ after incubation. This resistance to plant essential oils is also noted for several species of the genus Fusarium (Ouoba et al., 2018; Park et al., 2017). In an earlier study of the antifungal activity of the essential oil of Zanthoxylum Zanthoxyloides several fungi of the genus Fusarium (F.verticillioides, F.moniliforme) showed a resumption of growth four days after total inhibition of mycelial growth (Ouoba et al., 2018).

The phytotoxicity test of the essential oil used at a concentration of $0.50 \%$ has no phytotoxic effect on the emergence of sorghum seedlings. The biomass parameters of seedlings did not indicate a significant difference with the control fungicide. These results are similar to other studies that have shown that some plant essential oils have no toxicity on seeds and seedlings (Sorro et al., 2011). On the other hand, some authors have shown that the essential oils of certain plants can be toxic on seedlings (Vidal et al., 2018; El idrissi, EL Hurri, Amechrouq, \& Boughdad, 2014). The essential oil of Vitex simplicifolia did not show a toxicity in this study deserves particular attention as for its valuation in organic farming.

\section{Conclusion and Perspectives}

The essential oil of Vitex simplicifolia showed a variable antifungal activity on the seven phytopathogenic fungi studied. An increase in antifungal activity was noted with increasing concentration of essential oil. The increase in 
the amount of essential oil on the three most sensitive fungi ( $F$. moniliforme, $C$. graminicola and $C$. lunata) accentuated its inhibitory effect on mycelial growth. For the three fungi tested at 0.25 and $0.50 \%$ essential oil, only F. moniliforme has an inhibition percentage less than $50 \%$ at the fourth $(45.58 \%)$ and at the seventh day $(45.92 \%)$ after incubation. The fungus which showed a high sensitivity to the essential oil at $0.5 \%$ is $C$. graminicola with an inhibition percentage of $77.21 \%$. In addition, the phytotoxicity test conducted on Sorghum seeds indicates a non-toxicity of this essential oil.

Based on these results, the essential oil of Vitex simplicifolia leaves could be used as a natural fungicide for crop protection against phytopathogenic fungi. Achieving these objectives involves maintaining the specie in the plant heritage of our forests. In fact, the irrational use of the plant by farmers and traditional healers gradually leads to its disappearance in our forests. Therefore, extensive studies of its antifungal activity should be conducted on other crops and per fungus, to determine optimal and non-phytotoxic concentrations.

\section{References}

Arbonnier, M. (2002). Arbres, arbustes et lianes des zones sèches d'Afrique de l'Ouest (p. 573). CIRAD-MNHN-UICN, Paris, France.

Elidrissi, M., Elhourri, M., Amechrouq, A., \& Zouhair, R. (2014). Phytotoxicity activity of essential oil Chenopodium ambrosioides (L.) (Chenopodiaceae) and Daucus carota (L) (lamiaceae) on germination and radicle growth of seeds Lepodium sativum. Science Lib Editions Mersenne, 6.

FAOSTAT. (2016). Retrieved July 2, 2018, from http://www.faostat.org

Gbogbo, A. K., Batawila, K., Kouassi, A., Mireille, P. D., Gbeassor, M., Bouchet, P., \& Akpagana, K. (2013). Activité antifongique des huiles essentielles de Ocimum basilicum L. (Lamiaceae) et Cymbopogon schoenanthus (L.) Spreng Poaceae) sur des micromycètes influençant la germination du Maïs et du Niébé. Acta Botanica Gallica, 153(1), 124. https://doi.org/10.1080/12538078.2006.10515526

Hmiri, S., Rahouti, M., Habib, Z., Satrani, B., Ghanmi, M., \& El Ajjouri, M. (2011). Evaluation du potentiel antifongique des huiles essentielles de Mentha pulegium et d'Eucalyptus camaldulensis dans la lutte biologique contre les champignons responsables de la détérioration des pommes en conservation. Bulletin de la Société Royale des Sciences de Liège, 80, 824-836.

Mathur, S. B., \& Kongsdal, O. (2003). An illustrated Handbook on Normal and Abnormal Seedlings of Tropical and Sub-Tropical Crops (1st ed., p. 101). Danish Government Institute of Seed Pathology for Developing Countries, Copenhagen, Danmark.

Mathur, S. B., \& Kongsdal, O. (2003). Common laboratory seed health testing methods for Detection fungi (1st ed., p. 436). Kandrups Bogtrykkeri Edition.

Nazzaro, F., Fratianni, F., Coppola, R., \& De Feo, V. (2017). Essential Oils and Antifungal Activity. Pharmaceuticals, 10(4), 86. https://doi.org/10.3390/ph10040086

Nebié, R. C. H. (2006). Etudes des huiles essentielles de plantes aromatiques du Burkina Faso: Production, Composition chimique et Propriétés insecticides (p. 175, Thèse de Doctorat d'Etat ès Sciences Physiques (Chimie Organique: structure et réactivité), Unité de Formation et de Recherche/Sciences Exactes et Appliquées, Université de Ouagadougou, Burkina Faso).

Ouattara, L., Koudou, J., Obame, L. C. E., Karou, D. S., Traore, A., \& Bessiere, J.-M. (2007). Chemical Composition and Antibacterial Activity of Cochlospermum planchoni Hook.f. ex Planch Essential Oil from Burkina Faso. Pakistan Journal of Biological Sciences, 10, 4177-4179. https://doi.org/10.3923/pjbs. 2007.4177.4179

Ouoba, A. M., Koudou J., Somé, N., \& Guissou, L. P. (2009). Volatile Components of the Leaves of Vitex simplicifolia Oliv. Asian Journal of Chemistry, 21(4), 3304-3306.

Ouoba, P., Ouattara, L., Bonzi, S., Yaméogo, J. T., \& SomdA, I. (2018). Evaluation of antifungal activity and phytotoxicity of the essential oil of Zanthoxylum zanthoxyloides fruits. Agricultural Science Research Journal, 8(4), 92-99.

Park, J. Y., Kim, S. H., Kim, N. H., Lee, S. W., Jeun, Y. C., \& Hong, J. K. (2017). Differential Inhibitory Activities of Four Plant Essential Oils on In Vitro Growth of Fusarium oxysporum f. sp. fragariae Causing Fusarium Wilt in Strawberry Plants. Plant Pathol. J., 33(6), 582-588.

Satrani, B. (2001). Composition chimique et activité antimicrobienne des huiles essentielle de Satureja calamininthe et Satureja alpina du Maroc. Ann. Falsil. Epert. Chim., 94(956), 241-250. 
Somda, I., Sanon, P., Michaud, J. M., \& Sanou, J. (2003). Efficacité des extraits aqueux de citronnelle et de pourpier dans la lutte contre les champignons transmis par les semences de maïs. Science et technique, Série Sciences Naturelles et Agronomie, 27(1-2), 29-40.

Somda, I., Sanou, J., \& Sanon, P. (2008). Seed-Borne Infection of Farmer-Saved Maize Seeds by Pathogenic Fungi and Their Transmission to Seedlings. Plant Pathology Journal, 7(1), 98-103. https://doi.org/10.3923/ ppj.2008.98.103

Soro, S., Abo, K., Koné, D., Coffi, K., Kouadio, J. Y., \& Ake, S. (2011). Comparaison de l'efficacité antifongique de l'huile essentielle d'Ocimum gratissimum L.et du fongicide de synthèse Mancozebe contre le mycopathogène tellurique, Fusarium oxysporum f. sp. Radicis-lycopersici en culture de tomate (Lycopersicon esculentum Mill.) sous abri en Côte d'Ivoire. Agronomie Africaine, 23(1), 43-52.

Vidal, R., Muchembled, J., Deweer, C., Tournant, L., Corroyer, N., \& Flammier, S. (2018). Évaluation de l'intérêt de l'utilisation d'huiles essentielles dans des stratégies de protection des cultures. Innovations Agronomiques, 63,191-210.

Yoshimura, H., Sawai, Y., Tamotsu, S., \& Sakai, A. (2011). 1, 8-cineole inhibits both proliferation and elongation of BY-2 cultured tobacco cells. J. Chem. Ecol., 37(3), 320-328. https://doi.org/10.1007/s10886-011-9919-2

Zida, P. E., Lund, O. S., \& Néya, J. B. (2012). Seed treatment with a binary pesticide and aqueous extract of Eclipta alba (L.) Hassk. for improving sorghum yield in Burkina Faso. Journal of Tropical Agriculture, 50(1), 1-7.

\section{Copyrights}

Copyright for this article is retained by the author(s), with first publication rights granted to the journal.

This is an open-access article distributed under the terms and conditions of the Creative Commons Attribution license (http://creativecommons.org/licenses/by/4.0/). 